\title{
Lactic Acid Production from Fresh Cassava Roots Using Single-Stage Membrane Bioreactor
}

\author{
Suripto Dwi Yuwono \& Sutopo Hadi \\ Department of Chemistry, University of Lampung, Bandar Lampung 35145, Indonesia \\ E-mail: yuwen_5774@yahoo.com; sutopohadi@unila.ac.id
}

Fitriani \& Takao Kokugan

Department of Chemical Engineering, Tokyo University of Agriculture and Technology 22416, Nakamchi Koganei, Tokyo 1848588

Received: October 8, 2011

Accepted: November 25, $2011 \quad$ Published: January 1, 2012

doi:10.5539/mas.v6n1p60

URL: http://dx.doi.org/10.5539/mas.v6n1p60

\begin{abstract}
The production of lactic acid from fresh cassava roots by Steptococcus bovis using membrane bioreactor was investigated. Single-stage membrane bioreactor (MBR) without purging was conducted to find out the concentration and productivity of the lactic acid obtained. The result showed that in a single stage MBR, the lactic acid productivity and concentration were $1.88 \mathrm{~g} / \mathrm{Lh}$ and $15.7 \mathrm{~g} / \mathrm{L}$, respectively which were obtained at dilution rate of $0.12 \mathrm{~h}^{-1}$ and $30 \mathrm{~g} / \mathrm{L}$ feeding sugar concentration. The result also indicated that the MBR bioreactor operation showed excellently and potentially for the production of lactic acid directly from fresh cassava roots by S. bovis.
\end{abstract}

Keywords: Lactic acid, Single-stage reactor, S. bovis, Cassava roots

\section{Introduction}

Over the last decade, lactic acid production has attracted considerable attention, because lactic acid is a raw material for synthesis of polylactic acid (PLA) which is an essential bioplastics material (Datta et al., 1995). The production of PLA from biomass is expected to be environmentally friendly, effective for reducing $\mathrm{CO}_{2}$ gas emission and for saving fossil resources. However, the use of PLA is still limited because its production cost is 3 to 10 times higher than that of conventional plastics from fossil fuel resources. In order to reduce the production cost of PLA, we proposed an onsite cell plant method for the production of PLA by fermentation, separation and polymerization in sequential production step. For fermentation, a cheap fresh cassava roots was used as raw material and also the direct fermentation without saccharification was conducted by previous study (Ghofar, et al., 2005; Yuwono and Kokugan, 2007). For polymerization process, direct polycondensation method without catalyst and solvent was used to synthesize PLA as replacing of the high cost ring opening polymerization method (Achmad, et al., 2009).

Conventional methods of fermentation that use fretee cells in batch process have several limitations, such as low productivity, product inhibition and batch to batch variation in the product (Mehaia and Cheryan, 1987). The effect of product inhibitions on lactic acid fermentation has been by reported by Yuwono et al. (2008). Continuous fermentation, on the other hand, although has been known to overcome some of the problems associated with batch processes, is limited by cell wash-out (Tejayadi and Cheryan, 1995). In order to increase the productivity significantly, it is necessary to use high cell concentrations and to remove the inhibitory product (lactic acid).

Membrane bioreactor, an integrated process of fermentation and separation, as a compact process has the valuable advantages in order to increase lactic acid productivity. This process is expected to reduce product inhibition, reuse unconverted substrate, obtain high cell density culture, and decrease separation load of the next separation process (Tejayadi and Cheryan, 1995). By the optimization of these advantages, it is expected to reduce cost production of PLA in on-site cell plant.

In this research, membrane bioreactor with a ceramic monolith-type microfiltration membrane was used for production of lactic acid from fresh cassava roots as raw material. The efficiency of membrane bioreactor in 
terms of maximum lactic acid concentration and lactic acid productivity was investigated. One case of membrane bioreactor, single stage without purging was conducted.

\section{Experiment}

\subsection{Microorganism and Culture Conditions}

Streptococcus bovis JCM 5802 (RIKEN, Saitama, Japan) was used for L-lactic acid fermentation in this study. The bacteria was cultured in $5 \mathrm{~mL}$ of MRS medium (Difco, Sparks, MD, USA) consisting of $10 \mathrm{~g}$ of peptone (casein peptone tryptic digest), $10 \mathrm{~g}$ of meat extract, $5 \mathrm{~g}$ of yeast extract, $20 \mathrm{~g}$ or glucose, $2 \mathrm{~g}$ of $\mathrm{K}_{2} \mathrm{HPO}_{4}, 5 \mathrm{~g}$ of sodium acetate, $2 \mathrm{~g}$ of diammonium citrate, $0.1 \mathrm{~g}$ of $\mathrm{MgSO}_{4} \cdot 7 \mathrm{H}_{2} \mathrm{O}, 0.05 \mathrm{~g}$ of $\mathrm{MnSO}_{4} \cdot \mathrm{H}_{2} \mathrm{O}, 1 \mathrm{~g}$ of Tween 80 (poly sorbit-80) per liter of distilled water. After $18 \mathrm{~h}$ of incubation at $37^{\circ} \mathrm{C}$, the cultures were divided into $0.3 \mathrm{ml}$ of aliquots (around $106 \mathrm{CFU} / \mathrm{ml}$ ) per microtube and the cells were resuspended in skim milk, and then stored at $-80^{\circ} \mathrm{C}$. Precultures were prepared by transferring a stock culture to $5 \mathrm{ml}$ of MRS medium and incubated at $37^{\circ} \mathrm{C}$ for $18 \mathrm{~h}$ and used as an inoculum for the fermentation process.

\subsection{Media Fermentation}

Fresh cassava roots (FCR) used as substrate, directly supplied from Indonesia, were crushed and then stored in a freezer. A basic medium (glucose) and tapioca (cassava starch) were also used for comparison. Tryptosoya broth (Nissui Pharmeutical, Tokyo) which consisted of $20 \mathrm{~g}$ of peptone, $2.5 \mathrm{~g}$ of glucose, $2.5 \mathrm{~g}$ of $\mathrm{K}_{2} \mathrm{HPO}_{4}, 2.5 \mathrm{~g}$ of $\mathrm{KH}_{2} \mathrm{PO}_{4}$ and $5 \mathrm{~g}$ of NaCl per liter of distilled water, was used as basal medium. The substrate and medium were mixed and autoclaved at $121^{\circ} \mathrm{C}$ for $20 \mathrm{~min}$.

\subsection{Single-Stage Membrane Bioreactor}

A fermentor having a working volume of $3 \mathrm{~L}$ was used in the following operating modes: batch, conventional continuous fermentation, complete cell recycling. The fermentation was carried out under anaerobic conditions at $39^{\circ} \mathrm{C}$ and $\mathrm{pH}$ was maintained at 5.5 by automatic addition of $5.5 \mathrm{~N} \mathrm{NH}_{4} \mathrm{OH}$ solution. Constant stirring at 360 $+/-3 \mathrm{rpm}$ was kept during the fermentation.

The batch fermentation set-up consisted of a simple pH-controlled system. The set-up for cell recycling with membrane separation (membrane bioreactor) is shown in Figure 1. The system was initially operated in batch mode and switched to continuous mode or cell recycling mode after $24 \mathrm{~h}$ when the residual starch concentration was about $0.2-0.5 \mathrm{~g} / \mathrm{L}$. The fresh medium was feeding continuously with feeding pump which connected to the level controller to maintain a constant working volume. For continuous fermentation mode, the fermentation broth was then pumped to the stored tank at certain flow rate. For continuous cell recycling mode, the amount of fermentation broth was pumped by magnetic gear pump (Iwaki, Type MDG-H15KA200, Japan) at certain flow rate to a membrane system. A ceramic monolith-type membrane (Cefilt, NGK Filtech, Japan) with $50 \mathrm{~cm}$ long, 37 holes with $3 \mathrm{~mm}$ diameter and a surface area $0.174 \mathrm{~m}^{2}$ was used. A hold-up volume in the connection pipe and the membrane system was about $400 \mathrm{ml}$. The retentate was returned back to the fermentor and the permeate was then collected. The pressure was adjusted manually with pressure regulating valve and monitored with pressure gauge.

\subsection{Analysis}

The concentrations of L-lactic acid and residual starch (as glucose concentration) were analyzed using a biosensor (Oji Scientific Instruments, Osaka). Residual starch was measured by conversion to glucose by addition of glucoamylase enzyme and put in water bath at $50{ }^{\circ} \mathrm{C}$ for $4 \mathrm{~h}$. Aliquots of the fermented broth samples were aseptically collected. Viable cells of S. Bovis $(\mathrm{CFU} / \mathrm{ml})$ in the diluted samples $(0.1 \mathrm{~mL})$ were counted by the plate count method using bromocresol purple agar medium (Nissui Pharmaceutical, Tokyo) after anaerobic incubation for $72 \mathrm{~h}$ at $37^{\circ} \mathrm{C}$.

\section{Results and Discussion}

\subsection{Single Stage Membrane Bioreactor: Fermentation of Various Carbon Sources}

Figure 2 shows the results of fermentation of various carbon sources (FCR, tapioca, glucose) in terms of lactic acid concentration (a), residual sugar concentration (b) and viable cells (c). For all variations, batch fermentation was first conducted for $24 \mathrm{hr}$ at initial sugar concentration $\left(\mathrm{C}_{\mathrm{So}_{\mathrm{o}}}\right)$ of $40 \mathrm{~g} / \mathrm{L}$. Subsequently, continuous membrane bioreactor (MBR) was carried out with feeding sugar concentration $\left(\mathrm{C}_{\mathrm{Sf}}\right)$ of $30 \mathrm{~g} / \mathrm{L}$ and dilution rate (D) of 0.12 $\mathrm{h}^{-1}$. It can be seen that for batch operation, after $24 \mathrm{~h}$, lactic acid concentration for FCR was the highest among the other carbon sources. Moreover, residual sugar concentration of FCR was nearly zero after $72 \mathrm{~h}$ operation and the lowest among other carbon sources. On the other hand, lactic acid concentration for glucose was the lowest among the other carbon sources and the residual sugar concentration of glucose was the higher among the 
other carbon source. For subsequent MBR, the results show the same tendency with that in batch operation.

This result is in agreement with the study by Ghofar et al. (2005) where they conducted batch fermentation of FCR, tapioca, and glucose in different basal media by $S$. bovis. FCR was found to be more suitable for $S$. bovis compare to other carbon sources. This is due to $S$. bovis has the ability to directly produce lactic acid from starch because $S$. bovis secretes $\alpha$-amylase (Narita, et al., 2004; Satoh, et al., 1993). The starch is saccharified by extracellular $\alpha$-amylase to maltooligosaccharde. Subsequently, intracellular $\alpha$-amylase liquefies the olisaccharides to glucose inside the cell (Cotta, 1997, Satoh, et al., 1997). Then, S. bovis simultaneously converts glucose into lactic acid. It was known that $S$. bovis grown in a medium containing starch, as the carbon source, the organism has more $\alpha$-amylase activity than when cultured in a medium containing glucose (Cotta, 1988). It can also be seen that the viability cells of FRC is the highest among other carbon sources for the consecutive operation, batch and MBR (Figure 5).

\subsection{Effect of Feeding Sugar Concentration}

Figure 3 shows the effect of feeding concentration of sugar concentration (FCR) on lactic acid concentration (a), residual sugar concentration (b) and viable cells (c). The initial sugar concentration $\left(\mathrm{C}_{\mathrm{So}}\right)$ was $40 \mathrm{~g} / \mathrm{L}$, and the dilution rate (D) was kept at $0.07 \mathrm{~h}^{-1}$. The results show that after $24 \mathrm{~h}$ or batch operation, $32 \mathrm{~g} / \mathrm{L}$ lactic acid concentration and no residual sugar concentration were obtained. When MBR operation started, lactic acid concentration suddenly decreased and the steady-state value at about $14 \mathrm{~g} / \mathrm{l}$ was obtained after about $48 \mathrm{~h}$ operation for both varied sugar concentrations. Residual sugar concentration increased when MBR operation started and decreased after about $30 \mathrm{~h}$ for feeding sugar concentration $\left(\mathrm{C}_{\mathrm{Sf}}\right)$ of $30 \mathrm{~g} / \mathrm{L}$. However, residual sugar concentration was almost constant at about $14 \mathrm{~g} / \mathrm{L}$ for feeding sugar concentration $\left(\mathrm{C}_{\mathrm{Sf}}\right)$ of $50 \mathrm{~g} / \mathrm{L}$. It can be understood the sugar can not be completely converted to lactic acid at higher feeding sugar concentration. This could be due to the reaction time to complete sugar consumption has not yet been achieved at the given dilution rate. The substrate inhibition occurred at $50 \mathrm{~g} / \mathrm{L}$ sugar concentration was also presumed. Zhang and Cheryan (1994) have reported the study of starch fermentation by membrane bioreactor with L. amylovorus as strain. They found that lactic acid concentration was higher at $50 \mathrm{~g} / \mathrm{L}$ sugar concentration than that at $90 \mathrm{~g} / \mathrm{L} \mathrm{sugar}$ concentration.

Viable cells count increased until $12 \mathrm{~h}$ operation and then decreased due to lack of sugar concentration for batch operation (Figure 3c). When MBR started from $24 \mathrm{~h}$ operation, the viable cells stayed decreasing until $30 \mathrm{~h}$ operation and it started growing until the steady-state value at about $8.69 \times 10^{8} \mathrm{CFU} / \mathrm{mL}$ (feeding sugar concentration of $30 \mathrm{~g} / \mathrm{L}$ ) and $6.72 \times 10^{8} \mathrm{CFU} / \mathrm{mL}$ (feeding sugar concentration of $50 \mathrm{~g} / \mathrm{L}$ ) were achieved. It was generally known that the cell concentration, in terms of dry cell weight, can be increased as the operating time increased at MBR operation because cell was rejected by membrane and recycled back to the fermentor as reported by several studies (Hayakawa, et al., 1990, Xavier, et al., 1995, Hu, et al., 2006). However, the viable cells have not been mentioned clearly. Our study shows that the viable cells remained constant even cell concentration (in term of cell dry weight) increased. Because during the process, the livings cells undergo stress, which result in change in physiology (decrease of global activity and of viability) and possibly in morphology (appearance of cell damage and lysis) (Toma, et al., 2000).

\subsection{Effect of Dilution Rate}

Figure 4 shows the effect of dilution rate on lactic acid concentration (a), residual substrate (b) and viable cells (c) at initial sugar concentration $\left(\mathrm{C}_{\mathrm{So}}\right)$ of $40 \mathrm{~g} / \mathrm{L}$ and feeding concentration $\left(\mathrm{C}_{\mathrm{Sf}}\right)$ of $30 \mathrm{~g} / \mathrm{L}$. The results show that about $30 \mathrm{~g} / \mathrm{L}$ lactic acid concentration and no residual sugar concentration were obtained after $24 \mathrm{~h}$ of batch operation. At the operation MBR, it shows that lactic acid concentration at dilution rate (D) of $0.12 \mathrm{~h}^{-1}$ (15.7 $\left.\mathrm{g} / \mathrm{L}\right)$ was higher than that of $0.07 \mathrm{~h}^{-1}(14.0 \mathrm{~g} / \mathrm{L})$ and the residual concentration at dilution rate of $0.12 \mathrm{~h}^{-1}$ was lower than that of $0.07 \mathrm{~h}^{-1}$. The viable cells was remain constant with similar degree for both dilution rates, about 8.69 $\times 10^{8} \mathrm{CFU} / \mathrm{ml}$ for dilution rate of $0.07 \mathrm{~h}^{-1}$ and about $7.44 \times 10^{8} \mathrm{CFU} / \mathrm{ml}$ for dilution rate of $0.12 \mathrm{~h}^{-1}$. Hipolito et al. (2002) have studied the fermentation of lactic acid from glucose by L. lactic with sugar concentration of 53 $\mathrm{g} / \mathrm{L}$. They found that lactic acid concentration increased from $36.8 \mathrm{~g} / \mathrm{L}$ to $38.6 \mathrm{~g} / \mathrm{L}$, residual sugar decreased from $0.6 \mathrm{~g} / \mathrm{L}$ to $0.24 \mathrm{~g} / \mathrm{L}$ as dilution rate increased from $0.44 \mathrm{~h}^{-1}$ to $0.5 \mathrm{~h}^{-1}$. They used high cell density at higher dilution rate so that higher lactic acid was obtained.

\subsection{Membrane Performance in Single-Stage Membrane Bioreactor}

Figure 5 shows the performance of the membrane in MBR operation at feeding sugar concentration $\left(\mathrm{C}_{\mathrm{Sf}}\right)$ of 30 $\mathrm{g} / \mathrm{L}$ and dilution rate (D) of $0.12 \mathrm{~h}^{-1}$. The recirculation flow was set-up at $4.8 \mathrm{~L} / \mathrm{min}$ which is equal to $0.31 \mathrm{~m} / \mathrm{s}$ cross-flow velocity. The membrane was first operated at low transmembrane pressure at $5 \mathrm{kPa}$. The result shows that cross-flow velocity decreased after $58 \mathrm{~h}$ operation and continued to decrease until very low cross-flow 
velocity after $106 \mathrm{~h}$ operation. This was due to the increase of fermentation broth viscosity since the cells was recycled back to the fermentor. The fermentation was stopped after $120 \mathrm{~h}$. Meanwhile the transmembrane pressure slightly increased during the operation and kept constant at about $10 \mathrm{kPa}$. Because there was no purging conducted during operation, the fermentation process can not be operated for long period. Therefore, we purposed two-stage membrane bioreactor with purging which will be mentioned in the following section.

In addition, during the membrane bioreactor operation, it was found that lactic acid and residual sugar passed through the membrane, the cell was completely rejected because no viable cells found in the permeate solution.

\section{Conclusions}

The production of lactic acid from fresh cassava roots by Steptococcus bovis using membrane bioreactor was investigated. Single-stage membrane bioreactor (MBR) without purging and two-stages MBR with purging was conducted and the lactic acid concentration and productivity was then compare to batch, fed-batch and continuous fermentation. For single stage MBR, $1.88 \mathrm{~g} / \mathrm{L} . \mathrm{h}$ lactic acid productivity and $15.7 \mathrm{~g} / \mathrm{L}$ lactic acid concentration were obtained at $0.12 \mathrm{~h}^{-1}$ dilution rate and $30 \mathrm{~g} / \mathrm{L}$ feeding sugar concentration. For two-stages MBR, at the same dilution rate and feeding concentration, $2.41 \mathrm{~g} / \mathrm{L}$ lactic acid productivity and $20.1 \mathrm{~g} / \mathrm{L}$ lactic acid concentration were obtained as the best results at purging ratio of 0.3 . Long time operation of two-stages MBR is expected because of the stability of the membrane used. In comparison with other operation modes (batch, fed-batch, continuous), high productivity of lactic acid was obtained by MBR. Therefore, MBR bioreactor operation shows the excellent potential for the production of lactic acid directly from fresh cassava roots by $S$. bovis.

\section{Acknowledgments}

The authors would like to thank to The Directorate of Research and Services, Directorate General of Higher Education, The Ministry of Cultural and Education of Republic of Indonesia that provide fund for this project to be undertaken through International Collaboration and Research Grant Scheme 2011 with contract number of $881 / \mathrm{UN} 26 / 8 / \mathrm{PL} / 2011$.

\section{References}

Achmad, F., Yamane, K., Quan, S., \& Kokugan, T. (2009). Synthesis of polylactic acid by direct polycondensation under vacuum without catalyst, solvents and initiator. Chemical Engineering Journal, 151, 342-350. http://dx.doi.org/10.1016/j.cej.2009.04.014

Cotta, M. A. (1992). Interaction of ruminal bacteria in the production and utilization of maltooligosaccharides from starch. Applied and Environmental Microbiology, 58, 48-54.

Cotta, M. A. (1988). Amylolytic activity of selected species of ruminal bacteria. Applied and Environmental Microbiology, 54, 772-776.

Datta, R., Tsai, S., Bonsignore, P., Moon, S. H., \& Frank, J. H. (1995).Technology and economic potential of poly (lactic acid) and lactic acid derivatives. FEMS Microbiology Reviews, 16, 221-231. http://dx.doi.org/10.1111/j.1574-6976.1995.tb00168.x

Ghofar, A., Ogawa, S., \& Kokugan, T. (2005). Production of L-Lactic acid from fresh cassava roots slurried with tofu liquid waste by Streptococcus bovis. Journal of Bioscience and Bioengineering, 100, 606-612. http://dx.doi.org/10.1263/jbb.100.606

Hayakawa, K., Sansawa, H., Nagamune, T. and Endo, I. (1990). High cell density culture of Lactobacillus casei by a cross-flow culture method based on kinetic properties of the microorganism. Journal of Fermentation and Bioengineering, 70, 404-408. http://dx.doi.org/10.1016/0922-338X(90)90122-D

Hipolito, C. N., Matsunaka, T., Kobayashi, G., Sonomoto, K., \& Ishizaki, A. (2002). Synchronized fresh cell bioreactor system for continuous L-(+)-lactic acid production using Lactococus lactis IO-1 in hydrolyzed sago starch. Journal of Bioscience and Bioengineering, 93, 281-287. http://dx.doi.org/10.1263/jbb.93.281

Mehaia, M. A., \& Cheryan, M. (1987). Production of lactic acid from sweet whey permeate concentrates. Process Biochemistry, 22, 185-188.

Narita, J., Nakahara, S., Fukuda, H. and Kondo, A. (2004). Efficient production of L(+)-lactic acid from raw starch by Steptococcus bovis 148. Journal of Bioscience and Bioengineering, 97, 423-425. PMid:16233654

Satoh, E., Niimura, Y., Uchimura, T., Kozaki, M., \& Komagata, K. (1993). Molecular cloning and expression of two a-amylase genes from Streptococcus bovis 148 in Escherichia coli. Applied and Environmental Microbiology, 59, 3669-3673. 
Satoh, E., Uchimura, T., Kudo, T., \& Komagata, K. (1997). Purification, characterization, and nucleotide sequence of an intracellular maltotriose-producing $\alpha$-amylase from Streptococcus bovis 148. Applied and Environmental Microbiology, 63, 4941-4944. PMid:9406414

Tejayadi, S., \& Cheryan, M. (1995). Lactic acid from cheese whey. Productivity and econimics of a continuous membrane bioreactor. Applied Microbiology and Biotechnology, 43, $242-248$. http://dx.doi.org/10.1007/BF00172819

Toma, M. K., Rukilisha, M. P., Vanags, J. J., Zeltina, M. O., Leite, M. P., \& Galinina, N. I. (2000). Inhibitions of microbial growth and metabolism by excess turbulence. Biotechnology and Bioengineering, 38, 552-556. http://dx.doi.org/10.1002/bit.260380514

Yuwono, S. D., \& Kokugan, T. (2007). Study of the effects of temperature and pH on lactic acid production from fresh cassava roots in tofu liquid waste by Streptococcus bovis. Biochemical Engineering Journal, 40, $175-183$. http://dx.doi.org/10.1016/j.bej.2007.12.004

Yuwono, S. D., Ghofar, A., \& Kokugan, T. (2008). Effect of product inhibition on L-lactic acid fermentation from fresh cassava roots in tofu liquid waste by Sterptococcus bovis. Japan Journal of Food Engineering, 9, 59-66.

Xavier, A. M. R. B., Goncalves, L. M. D., Moreira, J. L., \& Carrondo, M. J. T. (1995).Operational patterns affecting lactic acid production in ultrafiltration cell recycle bioreactor. Biotechnology and Bioengineering, 45, 320-327. http://dx.doi.org/10.1002/bit.260450406

Xu, G. Q., Wang, Y. H., Zhuang, Y. P., Zhang, S. L., \& Peng, H. Q. (2006). Development of a continuous cell-recycle fermentation system for production of lactic acid by Lactobacillus paracasei. Process Biochemistry, 41, 2458-2463. http://dx.doi.org/10.1016/j.procbio.2006.05.022

Zhang, D. X., \& Cheryan, M. (1994). Starch to lactic acid in a continuous membrane bioreactor, Process Biochemistry, 29, 145-150. http://dx.doi.org/10.1016/0032-9592(94)80008-1

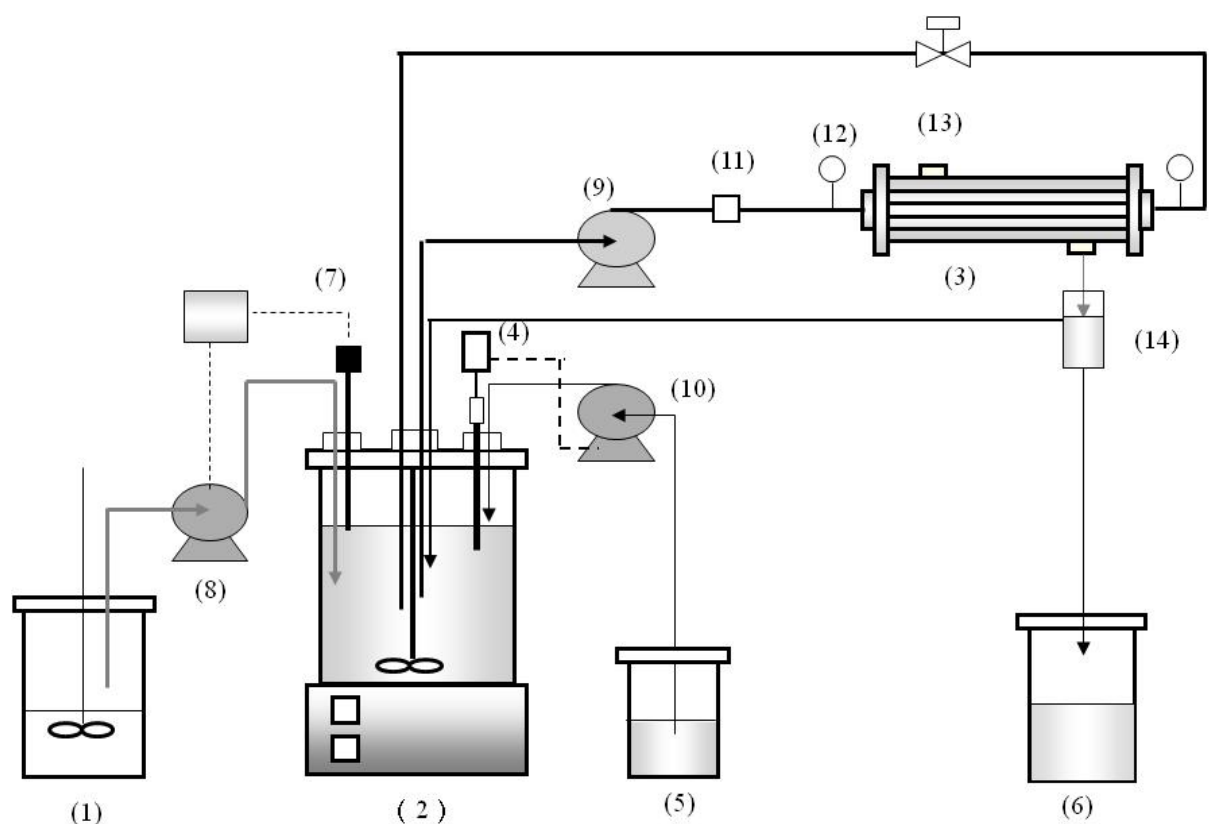

Figure 1. The experimental setup of single-stage membrane bioreactor

(1) feeding tank; (2) fermentor; (3) membrane module; (4) pH electrode; (5) neutralizing agent; (6) product tank; (7) level controller; (8) feeding pump; (9)recycle pump; (10) neutralizing pump; (11) flow meter; (12) pressure gauge; (13) pressure valve; (14) permeate separator 

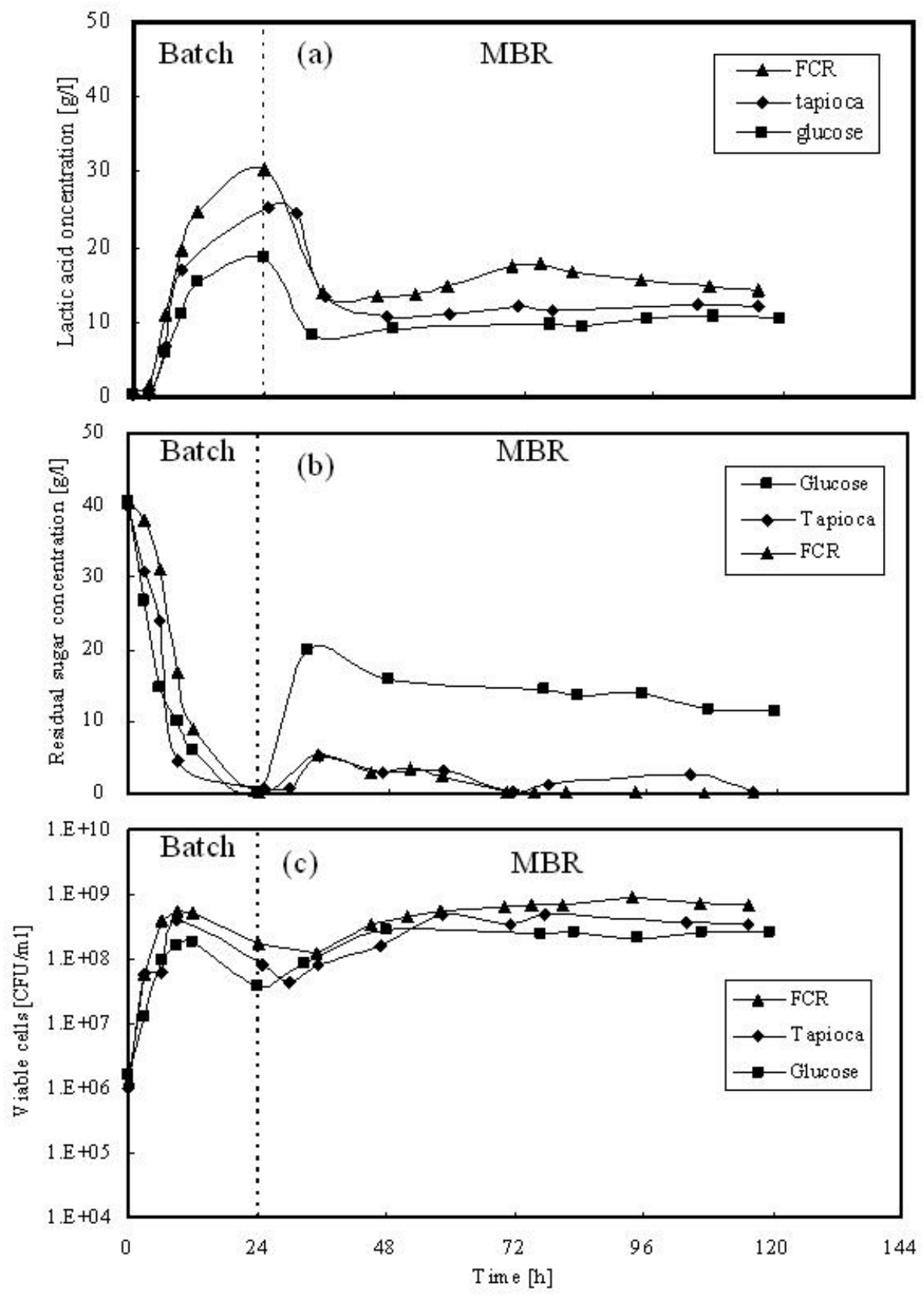

Figure 2. Fermentation of different raw materials using membrane bioreactor at $\mathrm{C}_{\mathrm{So}}=40 \mathrm{~g} / \mathrm{L}, \mathrm{C}_{\mathrm{Sf}}=30 \mathrm{~g} / \mathrm{L}, \mathrm{D}=$ $0.12 \mathrm{~h}^{-1}$ :lactic acid concentration (a), residual sugar concentration (b) and viable cells (c) 

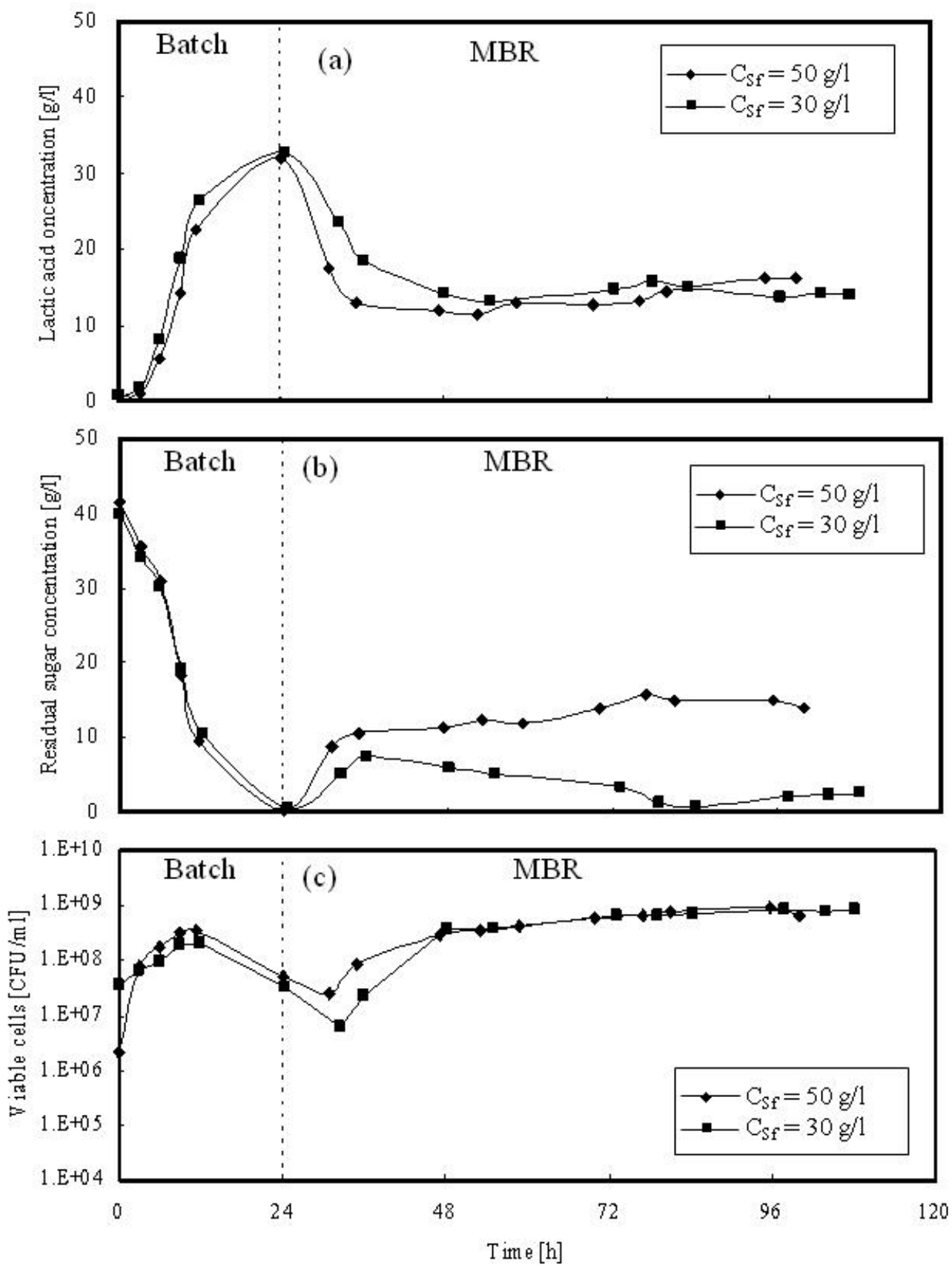

Figure 3. Effect of feed concentration on lactic acid concentration (a), residual sugar concentration (b) and viable cells (c) at $\mathrm{D}=0.07 \mathrm{~h}^{-1}$ 

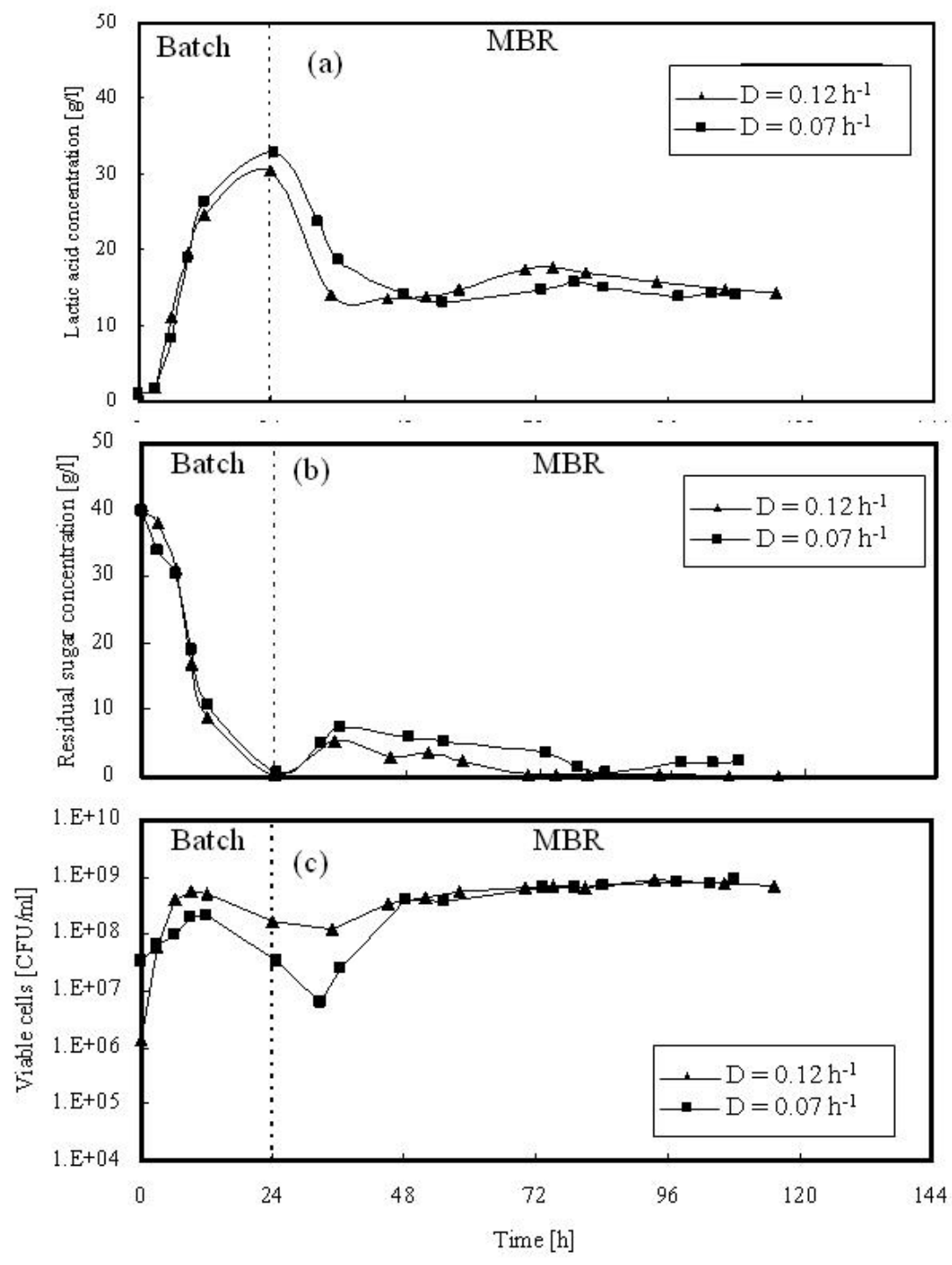

Figure 4. Effect of dilution rate on lactic acid concentration (a), residual sugar concentration (b) and viable cells (c) at $\mathrm{C}_{\mathrm{Sf}}=30 \mathrm{~g} / \mathrm{L}$

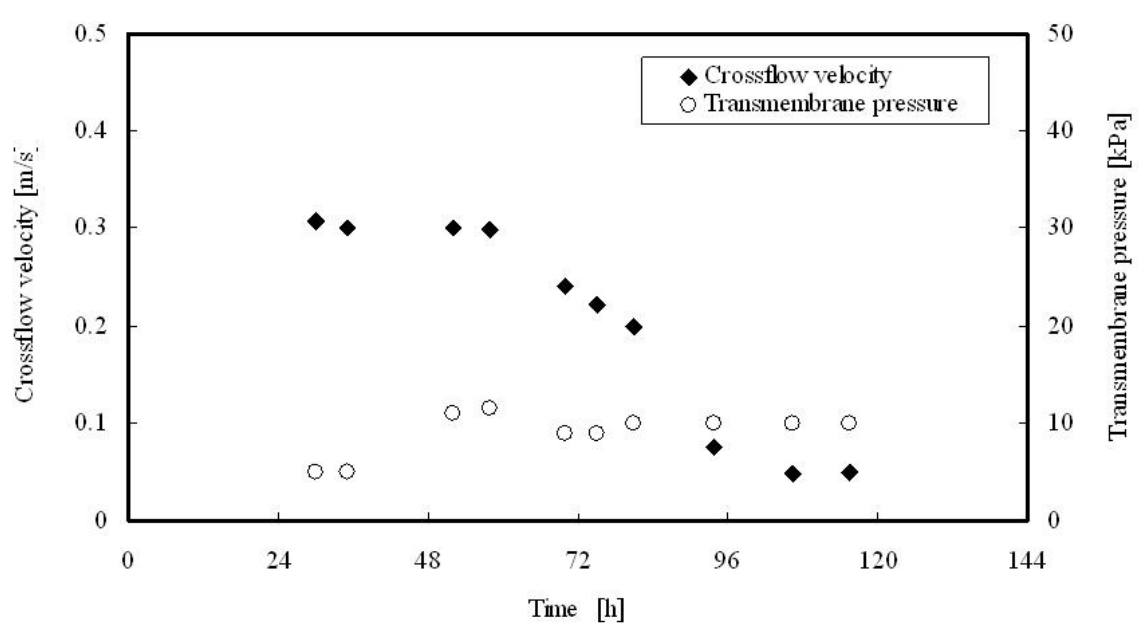

Figure 5. Membrane performance during membrane bioreactor operation at $\mathrm{C}_{\mathrm{Sf}}=30 \mathrm{~g} / \mathrm{L}$ and $\mathrm{D}=0.12 \mathrm{~h}^{-1}$ 